УДК: $\mathbf{3 7 2 . 8 7 8}$

DOI: https://doi.org/10.35619/iiu.v0i9.129

Потапчук Тетяна

доктор педагогічних наук, професор, професор кафедри теорії та методики дошкільної і спеціальної освіти ДВНЗ «Прикарпатський національний університет імені Василя

Стефаника»,

м. Івано-Франківськ, Україна

ORCID: 0000-0003-1680-6976

e-mail:tatvolod@ukr.net

\title{
ВИКОРИСТАННЯ ІННОВАЦИЙНО-ІНФОРМАЦЙНИХ ТЕХНОЛОГІЙ НА УРОКАХ МУЗИЧНОГО МИСТЕЦТВА
}

\begin{abstract}
Анотація. Процеси інформатизації сучасного освітнього простору нерозривно пов'язані 3 активним упровадженням інноваційно-інформаційних технологій, що урізноманітнює форми навчання й виховання. Застосування цих технологій в освіті завдяки їх специфічним властивостям значно посилює наочність у навчанні, емоційний вплив на учнів, сприяє поглибленню міжпредметних зв'язків, інтенсифікації роботи учнів, покращує організацію навчальної діяльності. Інноваційно-інформаційні технології відкривають нові можливості використання на уроках текстової, звукової, графічної та відеоінформації, збагачують методичні можливості уроку. Сьогодні використання цих технологій стає невід'ємною складовою вивчення будь-якого предмета. Використовуючи в навчальному процесі створені учнями мультимедійні презентації, публікації та веб-сайти, можна розвивати в них навчальні вміння та навички. Як зазначають дослідники, існує безліч мультимедійних програм для роботи 3 комп'ютером на уроці музичного мистецтва, а саме: музичний програвач, програма для співу карооке, музичний конструктор, музичні енциклопедії, навчальні програми, табличний процесор. Використання інноваційно-інформаційних технологій стає невід'ємною складовою вивчення будь-якого предмета. Упровадження інноваційно-інформаційних технологій у систему музичної освіти дозволяє розширити можливості навчання.

Ключові слова: інноваційно-інформаційні технології, уроки музичного мистецтва, мультимедійні засоби, музична культура, здібності.
\end{abstract}

Постановка проблеми. Сьогодні в музичній освіті відбувається активний пошук нових педагогічних методик, до яких ми відносимо інноваційно-інформаційні технології навчання. Музичне мистецтво відкривається перед дитиною як процес становлення художнього образу через різні форми художнього втілення (літературні, музичні, образотворчі). Урок музики стає не просто уроком розвитку сенсорних музичних здібностей, а уроком мистецтва, коли розвиваються всі психічні процеси: сприйняття, мислення, пам'ять, увага і т. i.

Аналіз останніх досліджень 3 проблеми. Проблемі застосування новітніх технологій (комп'ютеризація, інформатизація) у процесі навчання присвячена ціла низка праць вітчизняних і зарубіжних педагогів і психологів:
I. Вєтрова,
В. Вербунко,
П. Гальперін,
Б. Гершунський,
А. Гуржій, Ю. Машбиць та багато інших. 
Принципові положення теорії музичного розвитку розкриваються в дослідженнях Е. Абдулліна, В. Бєлобородова, В. Ветлугіна, Т. Дорошенко та ін.. Дослідниками визначалися різні аспекти проблеми розвитку музичної культури: їх природа, компоненти, критерії та показники розвитку, методи i прийоми розвитку. Більшість з цих питань все ж залишається дискусійним, що свідчать про складність та багатозначність досліджуваної проблеми.

Специфічні особливості музики як варіативність образів, абстрактність мови, інтегративні зв'язки, евристичні орієнтири, сприятливі для формування образно-асоціативного мислення, уяви, фантазії, художнього сприймання молодших школярів, досліджували Е. Печерська, Л. Радковська, О. Ростовський.

Мета статті - теоретично обгрунтувати використання інноваційноінформаційних технологій на уроках музичного мистецтва.

Виклад основного матеріалу дослідження. Упровадження інноваційноінформаційних технологій у систему мистецької освіти, зокрема музичної, дозволяє розширити можливості навчального середовища, що сприяє підвищенню якості навчання і допомагає задовольняти й розвивати пізнавальні інтереси учнів молодшого віку. Використання інноваційно-інформаційних технологій та мультимедії на уроках музичного мистецтва, означає появу нових форм розумової, творчої діяльності, які можна розглядати як історичний розвиток психічних процесів молодших школярів (Пивнева, 2008, с.119).

Сучасний урок - це поєднання традиційних технологій та нових інформаційних джерел, які передбачають використання теле- та радіомовлення, періодики, архівних матеріалів, ресурсів мережі Інтернет тощо. Це використання додаткового матеріалу, який можна знайти для різних категорій учнів і для різного рівня підготовки.

Урок 3 використанням інноваційно-інформаційних технологій (мультимедійний) - це звичайний урок, тільки більш технічно оснащений. Використання мультимедіа (інноваційно-інформаційних технологій) дозволяє організувати навчальний матеріал з урахуванням різних способів навчальної діяльності. Тут реалізуються такі рівні засвоєння навчального матеріалу:

1. Ілюстративно-описовий - візуальний ряд ілюструє традиційну розповідь учителя. Цей візуальний ряд надалі використовується при опитуванні й узагальненні. Візуальні образи можуть доповнюватись аудіо (музичним) матеріалом, що відіграє роль вступу-настроювання на стиль (епохи, школи, композитора), фону, ілюстрації та демонстрації (сприймання музично-дидактичних творів та їх фрагментів).

2. Схематичний - в основу навчання покладено конструювання опорних конспектів або структурно-логічних схем. Навчальний матеріал стає більш наочним, яскравим, доповнений руховими елементами.

3. Інтерактивний. Поєднує елементи ілюстративного й схематичного підходів. Різниця лише в тому, що використання різноманітного візуального матеріалу, схем і анімацій поєднується, доповнюється залученням документів, уривків 3 різних джерел. Елементи анімації, ілюстрація на мультимедійній дошці дозволяє школярам отримати не лише первинне уявлення при вивченні конкретного музичного твору, але і систематизувати засвоєну інформацію (Гороль та Гуревич, 2007, с. 366). 
Сучасна методика розвитку музичної культури молодших школярів рекомендує таку послідовність компонентів уроку музичного мистецтва мультимедійного типу:

1. Вхід учнів до класу під музику. Музичне вітання.

2. Повідомлення теми, мети, завдань уроку, мотивація учіння школярів; бесіда за темою уроку.

3. Бесіда та слухання музики.

4. Розспівування, робота над вокально-хоровою вправою.

5. Робота над поспівкою.

6. Розучування та виконання пісні.

7. Гра на елементарних музичних інструментах.

8. Рухи під музику: танці, пластичне інтонування, диригування, інсценізація, гра.

9. Музичні творчі завдання, живописні та літературні творчі завдання.

10. Музична грамота як необхідна складова структурних елементів.

11. Підсумки уроку, повідомлення домашнього завдання; вихід із класу під музику (Гумінська, 2010, с.11-12).

Використання інноваційно-інформаційних технологій стає невід'ємною складовою вивчення будь-якого предмета. Упровадження інноваційноінформаційних технологій у систему музичної освіти дозволяє розширити можливості навчання, що сприяє підвищенню якості навчання і допомагає задовольняти й розвивати музичну культуру учнів молодших класів (Базелюк, 2008).

Ми можемо стверджувати, що в учителя музичного мистецтва, який запроваджує мультимедійні технології на уроках, значно розширюється методичний арсенал. По-перше, він має можливість швидше підготуватися до уроку, і прийти на урок не з купою конспектів, банерів, та нот, а $з$ диском або флеш-накопичувачем, на якому буде зберігати вся та інформація, але в цифровому варіанті. По-друге, перевагою мультимедійних технологій є їхня властивість зацікавити учнів музичним матеріалом. По-третє, застосування новітніх засобів інформаційних технологій в різних сферах людської діяльності активно впливає використання мультимедійних технологій у процесі навчання. Без комп'ютерних технологій в навчальному процесі сьогодні себе не мислить ні вчитель, ні учень. Практично доведено, що ці технології мають досить потужний вплив на ефективність уроку та зацікавленість і розвиток музичної культури молодших школярів (Гуревич та Кадемія, 2005, с.299-300).

Мультимедійні засоби $є$ ефективними освітніми технологіями зі властивими їм якостями, а саме: інтерактивності, гнучкості, та інтеграції різнотипової навчальної інформації, а також завдяки можливості враховувати індивідуальні особливості учнів і сприяти підвищенню їх мотивації.

Запровадження інноваційно-інформаційних технологій на уроках музичного мистецтва забезпечує вирішення таких завдань щодо всебічного розвитку музичної культури та творчих здібностей учнів молодших класів:

- відчуття простору, форми, контрасту, динаміки, кольорової палітри;

- асоціативного сприйняття і мислення на основі художнього і музичного матеріалів;

- фантазії і художньої уяви;

- розуміння цінності музичного мистецтва; 
- почуття ритму в природі і мистецтві.

Застосування мультимедійних засобів у навчальному процесі дозволяє:

- підвищити ефективність навчального процесу;

- розвинути особистісні якості школяра (здатність до самоосвіти, самовиховання, самонавчання, саморозвитку, творчі здібності, уміння застосовувати здобуті знання на практиці, пізнавальний інтерес тощо);

- розвинути комунікативні та соціальні здібності;

- істотно розширити можливості індивідуалізації і диференціації за рахунок надання кожному «персонального педагога», роль якого виконує комп'ютер;

- створити привабливі форми навчання, активізувати пізнавальний інтерес учнів;

- оволодіти навичками роботи із сучасними інформаційнокомунікаційними технологіями, що сприятиме його адаптації до швидкозмінних соціальних умов, для успішної реалізації своїх фахових якостей (Бордюк, 2011, с.71-77).

Використання мультимедійних технологій дозволяє залучити учнів до різних видів діяльності, а саме: пошукової роботи під час вивчення народної творчості, української музичної культури, творчості композиторів світу, створення творчих робіт, оформлення результатів своїх досліджень у вигляді методу проектів за певними темами.

Використовуючи в навчальному процесі створені учнями мультимедійні презентації, публікації та веб-сайти, можна розвивати в них такі навчальні вміння та навички, як: презентування (усно або виступ перед аудиторією), вміння стисло формулювати свою думку, навчитись якісно виконувати пошукову роботу тощо (Туріщева, 2006, с.36).

Як зазначають дослідники, існує безліч мультимедійних програм для роботи 3 комп'ютером на уроці музичного мистецтва. Це i музичний програвач, програма для співу карооке, музичний конструктор, музичні енциклопедії, навчальні програми, табличний процесор.

Впровадження мультимедійних технологій на уроці музичного мистецтва дає можливість використовувати педагогічний програмний засіб «Музичне мистецтво», презентації Microsoft PowerPoint, дозволяє використовувати комп'ютер як засіб для демонстрації наочності (твори живопису, портрети композиторів, тощо), прослуховувати музичні твори різних форматів, виконання пісень караоке, демонстрація фрагментів відеофільмів, проводити групове індивідуальне опитування учнів (тестування, кросворди, вікторини та iH.).

Використання мультимедійних презентацій Microsoft PowerPoint на уроках музичного мистецтва дає змогу організовувати демонстрації змісту уроку, завдань, підсумків роботи на уроках, демонстрування нот, таблиць, схем, результатів групових проектів, фрагментів музичних творів, портретів композиторів (Гороль та Гуревич, 2007).

За допомогою табличного процесора можна розробити тестові завдання, шаблони, ребуси, кросворди як додатковий матеріал для учнів.

Варто зазначити, що використання мультимедійних технологій забезпечує широкі дидактичні можливості й неможливе без сучасних технічних засобів навчання (рис.1). 
Головною метою створення дидактичних матеріалів $\epsilon$ управління процесом засвоєння учнями знань 3 конкретної теми, підсумовування їхньої дослідницької, пошукової або творчої діяльності.

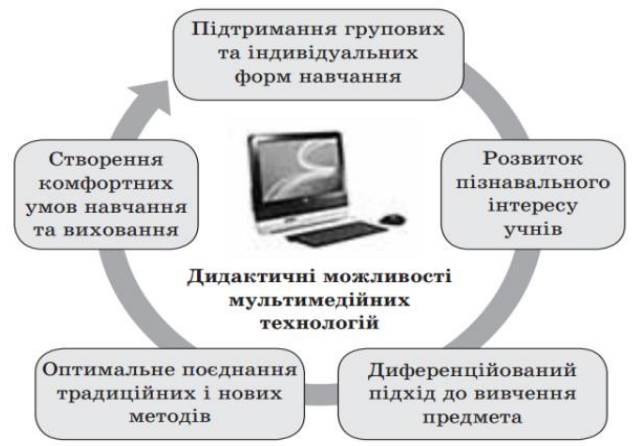

Рис.1. Дидактичні можливості мультимедійних технологій

Дидактичні матеріали, розроблені за допомогою табличного процесора, можуть передбачати перевірні тести, кросворди, таблиці. Такі матеріали допоможуть учням краще зрозуміти досліджувані проблеми, а також набути необхідних знань, умінь і навичок. Microsoft Excel являє собою потужний інструмент, призначений для опрацювання, аналізу й відображення даних за допомогою електронних таблиць. Це можуть бути різні дані, наприклад:

- тривалості нот, динамічні відтінки, лад.

- інформація з біографії чи музичної творчості композиторів;

- статистичні дані про популярність українських народних пісень.

Крім того, за допомогою табличного процесора учні можуть зберігати й аналізувати інформацію, швидше розучувати пісенний матеріал, використовуватии різноманітні практичні завдання, передбачати зміни, оцінювати результати, розглядати дані в різних формах, стежити за певними тенденціями музики i відображати їx у графіках, впорядковувати i класифікувати об'єкти тощо.

Отже, порівнюючи з традиційним, комп'ютеризоване музичне навчання $\epsilon$ прогресивнішим напрямом у системі сучасної музичної освіти.

Мультимедіа дозволяє полегшити і підказати аналітичну та систематичну роботу програмними засобами. Тому одним із найважливіших завдань навчання $€$ формування у молодших школярів активного ставлення до сприйняття i перетворення наочного матеріалу. Важливо не тільки вміти сприймати подану наочність, переосмислювати iï $з$ урахуванням навчального завдання, але й перекодовувати iï зміст. Ця вимога пов'язана 3 тим, що, працюючи 3 мультимедіа, учні молодших класів постійно мають справу 3 різнотипною наочною інформацією, переходять від використання одних видів умовних зображень до інших (Базелюк, 2008).

Урок музичного мистецтва зумовлює необхідність використовувати широке коло зразків високохудожнього виконання музичних творів у поєднанні $з$ творами інших видів мистецтва. Однією з очевидних переваг мультимедійного уроку $є$ широке використання наочності (що $€$ актуальним ще 
й тому, що сьогодні в школах зазвичай відсутній необхідний набір таблиць, схем, репродукцій, ілюстрацій). Учителі не завжди володіють належним виконавським рівнем, не в усіх школах $є$ відповідні інструменти для високохудожнього виконання музичних творів. Тому впровадження мультимедійних технологій у навчально-виховний процес на уроці музичного мистецтва суттєво впливатиме на підвищення рівня музичної культури учнів молодших класів, допоможе задовольнити їх творчі потреби.

Слід зазначити, що інноваційна діяльність $є$ специфічною i досить складною, потребує особливих знань, навичок, здібностей. У новаторській педагогіці достатньо різнобічно втілено творчу сутність навчально-виховного процесу (Дмітрієва, 2013).

Використання мультимедійних технологій дозволяє істотно підвищити рівень ефективності навчального процесу. Нові можливості для педагогіки мистецтва, відкривають комп'ютерні технології. Суб'єктивні фактори їх застосування залежать, насамперед, від рівня комп'ютерної грамотності вчителя.

Кожен учитель сьогодні має здійснювати комп'ютерну самоосвіту, застосувати комп'ютер для полегшення своєї праці, економії часу та підвищення якості освіти. Учитель музичного мистецтва має опанувати програму роботи з текстом (Microsoft Word), програму запису звука Audio CD (Ahead Nero), програму нотного набору та верстки музичного тексту (Finale), програми запису та обробки звука (Adobe Audition, Sound Forge), програму підготовки презентаційної графіки (Microsoft PowerPoint) (Гумінська, 2010, с. 21).

Проте поряд 3 очевидними перевагами мультимедійних технологій існують проблемні питання їхнього використання: для створення i використання мультимедійного матеріалу необхідні знання персонального комп'ютера та навички роботи зі спеціальним програмним забезпеченням, які, на жаль, є не у кожного вчителя або учня; проектування та оформлення мультимедійної продукції - кропіткий процес, який вимагає наявності певного часу, знань із різних наукових галузей та почуття міри у використанні інформації та спецефектів, зловживання якими можуть відволікати увагу в процесі навчання, тощо (Дементієвська, 2005, с. 227).

Вчені вважають, що комп'ютер сприяє розвитку розумових здібностей, творчого нестандартного мислення під час використання завдань, підвищує інтерес до навчання, сприяє набуттю знань і умінь, розкриває привабливі сторони різних галузей науки. Отже, комп'ютер надає нові можливості для розвитку здібностей учнів, активно включає іiі у навчальний процес, підвищує зацікавленість, сприяє кращому засвоєнню навчального матеріалу.

Впровадження сьогодні у загальноосвітній школі інноваційноінформаційних технологій є підтвердженням однієї з суттєвих тез сучасної педагогіки - чим краще, яскравіше, інформаційно насиченіше викладання, тим якісніша професійна підготовка молодших школярів, тим вищий рівень їхньої мотивації до навчання.

Однією 3 очевидних переваг мультимедійного уроку $\epsilon$ широке використання наочності (що $\epsilon$ актуальним і тому, що сьогодні в школах зазвичай відсутній необхідний набір таблиць, схем, репродукцій, ілюстрацій). Учителі не завжди володіють належним виконавським рівнем, не кожна школа має відповідні інструменти для високохудожнього виконання музичних творів. 
Тому упровадження мультимедійних технологій у навчально-виховний процес на уроці музичного мистецтва суттєво впливатиме на підвищення рівня музичної культури учнів, допоможе задовольнити їх творчі потреби.

Отже, впровадження інноваційно-інформаційних технологій у практику сучасної школи уможливлює поєднання дидактичних функцій комп'ютера 3 традиційними засобами навчання, збагачення i наповнення навчального процесу новими формами роботи, варіативне застосування ігрових форм навчання, створення інноваційних методик викладання музики в системі шкільної освіти, а також сприяє більш ефективному засвоєнню музичних знань та їх реалізації у музично-творчій діяльності (Тарачева, 2007, с. 43).

Мультимедійні засоби допомагають вчителю зробити процеси формування нових знань, умінь і навичок, засвоєння понять, узагальнення й перевірки знань цікавими та продуктивними.

Висновки i перспективи подальших розвідок. Узагальнюючи результати дослідження заявленої теми, варто наголосити що, завдячуючи впровадженню інноваційно-інформаційних технологій на уроках музичного мистецтва, з'являється можливість на високому, більш якісному рівні проводити «нестандартні» уроки.

Якщо послідовно й систематично використовувати на уроках музичного мистецтва комп'ютерні технології, стає легше контролювати творчий розвиток учнів, формувати музичні здібності, розвивати музичну культуру молодших школярів. У загальному розумінні інноваційно-інформаційні технології $\epsilon$ способом комбінування різних форм подачі інформації на одному носієві, у той час, як відео, аудіо, графіка, текст, анімація тощо $\epsilon$ основними компонентами мультимедійної системи.

Впровадження сьогодні у закладі середньої освіти мультимедійних освітніх технологій $є$ підтвердженням однієї з суттєвих тез сучасної педагогіки - чим краще, яскравіше, інформаційно насиченіше викладання, тим якісніша професійна підготовка школярів, тим вищий рівень їхньої мотивації до учіння.

Перспективи подальших досліджень вбачаємо у застосуванні інноваційно-інформаційних технологій на уроках мистецтва 3 учнями старших класів.

\section{СПИСОРК ВИКОРИСТАНИХ ДЖЕРЕЛ:}

Пивнева, Н. (2008). Информационные технологии на уроках музыки. В: Воронеж. $360 \mathrm{c.}$

Гороль, П. та Гуревич, Р. (2007). Сучасні інформащійні засоби навчання. К.: Освіта України. 536 с.

Гумінська, О. (2010). Уроки музики в загальноосвітній школі. Тернопіль: навчальна книга «Богдан». 104 с.

Базелюк, О. (2008). Мультимедіа-технологія - мистецтво. Мистецтво $i$ освіта, №3. сс. 16-18.

Гуревич, Р. та Кадемія, М. (2005). Інформаційно-телекомунікаційні технології в навчальному прочесі та наукових дослідженнях. Вінниця: ТОВ «Планер». 366 с.

Бордюк, О. (2011). Методичні засади реалізаиії інформаційно-комунікаичійних технологій в мистецькій освіті. К: Нац. пед. ун-т ім. М. П. Драгоманова. 370 с.

Туріщева, Л. (2006). Вікові аспекти виховання школяра. Виховна робота в школі, №8. сс. 36-41.

Дмітрієва, Л. (2013). Інформаційні технології на уроках музичного мистецтва. Мистецттво в школі, №1. сс. 2-5. 
Дементієвська, Н. (2005). Як можна комп'ютерні технологї використати для розвитку учнів та вчителів. К: Міленіум. 238 с.

Тарачева, О. (2007). Компьютерные технологии на уроках музыки. Искусство в школе, №6. сс. 43.

\title{
REFERENCES:
}

Pivneva, N. (2008). Informatsionnyie tehnologii na urokah muzyiki. [Information Technologies at Music Lessons]. V: Voronezh. 360 s. [in Russian].

Horol, P. ta Hurevych, R. (2007). Suchasni informatsiini zasoby navchannia. [Modern Information Means of Teaching]. K.: Osvita Ukrainy. 536 s. [in Ukrainian].

Huminska, O. (2010). Uroky muzyky v zahalnoosvitnii shkoli. [Music Lessons in secondary School]. Ternopil: navchalna knyha "Bohdan". 104 s. [in Ukrainian].

Bazeliuk, O. (2008). Multymedia-tekhnolohiia - mystetstvo. [Multimedia Technology - the Art]. Mystetstvo i osvita, No3. ss. 16-18. [in Ukrainian].

Hurevych, R. ta Kademiia, M. (2005). Informatsiino-telekomunikatsiini tekhnolohii $v$ navchalnomu protsesi ta naukovykh doslidzhenniakh. [Information and Telecommunication Technologies in the Educational Process and Scientific Researches]. Vinnytsia: TOV "Planer". 366 s. [in Ukrainian].

Bordiuk, O. (2011). Metodychni zasady realizatsii informatsiino-komunikatsiinykh tekhnolohii $v$ mystetskii osviti. [Methodical Principles of the Implementation of Information and Communication Technologies in Artistic Education]. K: Nats. ped. un-t im. M. P. Drahomanova. 370 s. [in Ukrainian].

Turishcheva, L. (2006). Vikovi aspekty vykhovannia shkoliara. [Age Aspects of Education of a Schoolchild]. Vykhovna robota $v$ shkoli, No8. ss. 36-41. [in Ukrainian].

Dmitriieva, L. (2013). Informatsiini tekhnolohii na urokakh muzychnoho mystetstva. [Information technologies at musical Art Lessons]. Mystetstvo v shkoli, No 1. ss. 2-5. [in Ukrainian].

Dementiyevska, N. (2005). Yak mozhna kompiuterni tekhnolohii vykorystaty dlia rozvytku uchniv ta vchyteliv. [How Computer Technologies Can Be Used for the Development of Students and Teachers]. K: Milenium. 238 s. [in Ukrainian].

Taracheva, O. (2007). Kompyuternyie tehnologii na urokah muzyki. [Computer Technologies at Music Lessons]. Iskusstvo v shkole, No6. ss. 43. [in Russian].

\section{THE USE OF INNOVATIVE INFORMATION TECHNOLOGIES AT THE MUSIC LESSONS}

Tetiana Potapchuk

Doctor in Pedagogy, Professor, Professor at the Department of Theory and Methodology of Preschool and Special Education Vasyl Stefanyk Precarpathian National University, Ivano-Frankivsk. Ukraine ORCID: 0000-0003-1680-6976 e-mail:tatvolod@ukr.net

\begin{abstract}
The processes of informatization of the modern educational space are inextricably linked with the active implementation of innovation and information technologies, which diversifies the forms of education and upbringing. The use of these technologies in education due to their specific properties greatly enhances the visibility of learning, emotional impact on students, promotes deepening of interpersonal relationships, intensifies the work of students, improves the organization of educational activities. innovative information technologies are a way of combining different forms of presenting information on one medium, while video, audio, graphics, text, animation, etc.
\end{abstract}


are the main components of the multimedia system. Innovative information technologies open new opportunities for using at the lessons text, sound, graphic and video information, enrich the methodological possibilities of the lesson. Nowadays, the use of these technologies becomes an integral part of the study of any subject.

The musical art lessons demand the use of a wide range of samples of highly artistic performance of musical works in combination with works of other types of art. One of the obvious benefits of a multimedia lesson is the widespread use of visibility (which is also relevant because today schools usually lack the necessary set of tables, schemes, reproductions, illustrations). Teachers do not always have a proper performance level, not every school has the appropriate tools for highly artistic performance of musical compositions. Therefore, the implementation of multimedia technologies in the educational process at the music art lessons will significantly affect the level of musical culture of students and help meet their creative needs.

Key words: innovation-information technologies, musical art lessons, multimedia means, musical culture, abilities.

Стаття надійшла до редакиії 03.05.2019 p. 